\title{
Review of Creosote Pollution Toxicity and Possibilities of Bioremediation
}

\author{
A. Jurys ${ }^{1}$, I. Gailiūtė ${ }^{1,4}$,J. Aikaitè-Stanaitiené ${ }^{1}$, S. Grigiškis ${ }^{1}$, A. Maruška ${ }^{2}$, \\ M. Stankevičius ${ }^{2}$, D. Levišauskas ${ }^{3}$ \\ 1 - JSC „Biocentras”, V. Graičiūno st. 10, LT 02241 Vilnius, Lithuania; Ph: + (370) 526613 13, \\ fax: + (370) 526024 54, e-mail: biocentras@biocentras.lt \\ 2 - Department of Biochemistry and Biotechnologies, Vytautas Magnus University, Vileikos st. 8, LT 44404 \\ Kaunas, Lithuania \\ Ph: +370 37327907 Fax: +370 37327908 , e-mail: a.maruska@gmf.vdu.lt \\ 3 - Process Control Department, Kaunas University of Technology Studentu st. 50, LT 51368 Kaunas, \\ Lithuania, e-mail: donatas.levisauskas@ktu.lt \\ 4 - Institute of Biotechnology, Vilnius University, V. A.Graičiūno st. 8, LT 02241, Vilnius, Lithuania.
}

\begin{abstract}
Creosote oil is a complex mixture of hydrocarbon compounds obtained from high temperature distillation of coal tar. It is used for over 100 years as a fungicide, insecticide, miticide, and sporicide to protect wood and is applied by pressure methods to wood products, primary utility poles and railroad ties. This treated wood is intended for exterior or outdoor uses only. Its commercial uses include railroad ties 70 \%, utility poles 15-20 \%, and other miscellaneous commercial uses 10-15 \%. Composition of the creosote depends on the source and it has typically $85 \%$ polycyclic aromatic hydrocarbons (PAHs), $10 \%$ phenolic compounds, and $5 \%$ heterocyclic. Between 20 and $40 \%$ of the total weight of typical creosote can be attributed to the 16 PAHs defined as priority pollutants by the United States Environmental Protection Agency (EPA). The production of creosote in the European Union (EU) has been estimated to be approximately 60.000-100.000 $t$ per year. The presence of the toxic PAHs and phenolic compounds make creosote treated wood harmful for the environment at the end of its service life and direct or indirect human exposure to creosote treated wood may cause carcinogenic affect to kidney, liver, bladder, eyes and skin. In this presentation we review creosote environmental pollution toxicity and possibilities of remediation
\end{abstract}

Keywords - creosote, PAH, pollution, remediation, toxicity.

\section{INTRODUCTION}

Wood-preserving industry uses more pesticides than any other industry worldwide. The one of major chemical employed for this purpose is creosote used in the wood treating industry for over 100 years. Wood treated with creosote is widely used, e.g., as poles for electric power or telephone lines and as railroad sleepers [1]. The production of creosote in the EU has been estimated to be approximately 60,000-100,000 t per year, preservation of railway uses $54 \%$ of creosote. [2]. When properly used and disposed of, creosote does not appear to significantly threaten human health. However, misuse, accidental spillage, and improper disposal of creosote results in contaminated environments with serious potential health risk. Creosote contamination is generally associated with surface soils, waters in treatment lagoons or evaporation areas, and groundwater contaminated with leachate from the above sources [3]. Creosote oil is a complex mixture of hydrocarbon compounds obtained from high temperature distillation of coal tar. Coal tar creosote is composed of approximately $85 \%$ polycyclic aromatic hydrocarbons (approx. $50 \%$ two-ring, $39 \%$ three-ring, $9 \%$ four-ring and $2 \%$ five-ring); $10 \%$ phenolic compounds; and $5 \% \mathrm{~N}-, \mathrm{S}-$, and O- heterocyclic [3-10]. Between 20 and $40 \%$ of the total weight of typical creosote can be attributed to the 16 PAHs defined as priority pollutants by EPA and EU (Fig.1), many of the
PAHs are recalcitrant compounds and have toxic properties.

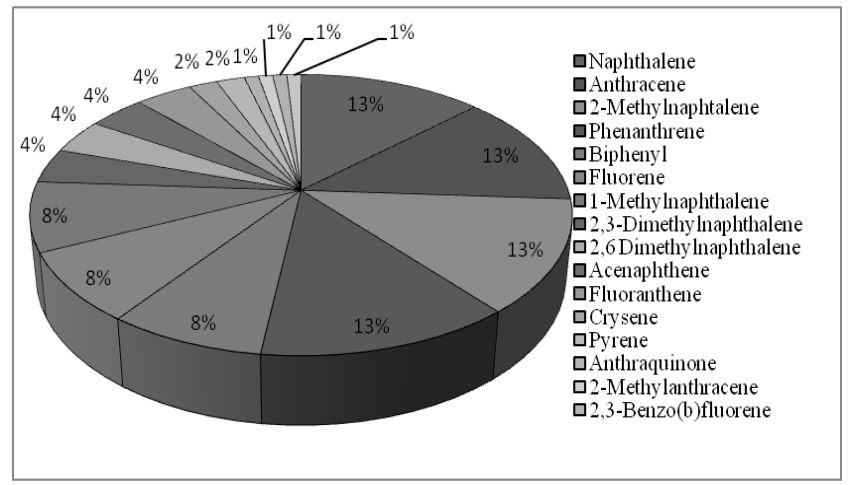

Fig.1. Predominant PAHs constituent in Creosote [3],[8],[11]

\section{CREOSOTE TOXICITY}

Creosote's qualities as a wood preservative are excellent; however accidental spillage, improper disposal results in contaminated environments with serious potential health risks. Creosote compounds are commonly occurring industrial pollutants and are often found as cocontaminants in the environment. Most of creosote consisting compounds are known as carcinogenic, teratogenic, genotoxic and imunotoxic [8, 12-16]. The effects on human health will depend mainly on the length 
and route of exposure, the amount or concentration of creosote compounds. Human exposure to creosote compounds occurs through 3 routes: respiratory tract, gastrointestinal tract and skin contact coming into direct contact with creosote and breathing in airborne creosote particles increase the chances for creosote exposure inside the body. Through the lungs and skin creosote will slowly pass into the bloodstream. Common external effects include rashes, either severe or mild, chemical burns around the eye area, sensitivity to light, eye damage and blistering or peeling skin. Internal damage can also occur from exposure to creosote from eating, drinking or breathing in the creosote chemicals [17]. Internal toxic damages can include unconsciousness, cancer, convulsions, mental impairment, kidney and liver problems and several other internal issues [18]. However, the industrialization of creosote has increased the amount of the chemical present in groundwater and soil. The creosote forms a tar-like substance in the water, where it takes many years to completely break down. One or two per cent of creosote used to treat wood ends up in the air [19]. Any plant or animal that is near the creosote in the water, air or soil absorbs the chemicals. Plants absorb less of the creosote than animals. The main danger of creosote exposure to the environment is then that the chemicals absorbed by the animals or plants move on to humans (Fig.2.).

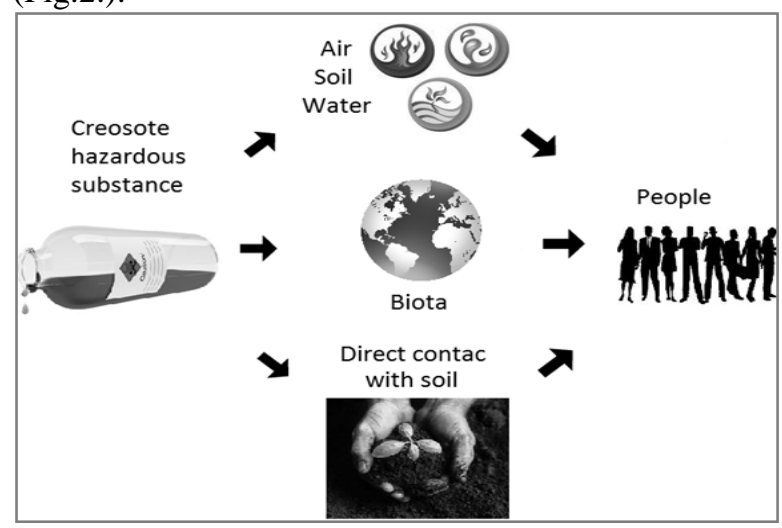

Fig. 2. Exposure pathways of creosote pollution.

\section{BIOREMEDIATION OF CREOSOTE}

Biological degradation is the primary dissipation mechanism for the most of organic pollutants in the environment, however the activity of degrading microorganisms depends upon many factors, including contaminant uptake and bioavailability, concentration, toxicity, mobility access to other nutrients and activated enzymes [11]. The rate and extent of biodegradation of creosote in soils and sediments is affected by multiple factors, such as physico-chemical (physical/chemical properties of PAHs, phenols, heterocycles, organic content of soil, structure/particle size of soil, presence of contaminants), biological factors (characteristics of the microbial population: diversity, genetic/catabolic potential) and environmental factors (temperature, moisture, $\mathrm{pH}$, sorption, degree of contamination).

Two-ringed PAH as naphthalene is broken down easily. The three-ring PAHs, such as acenaphtalene, fluorene, phenanthrene, anthracene and the four-ring PAHs such as fluoranthrene, pyrene, benzo(a)anthracene and crysene have been shown to be metabolized by microorganisms and degraded in creosote bioremediation although at slower rates as the molecular weight increases. However, the high-molecular weight five, six, seven ring PAHs, such as benzo(b)fluoranthene, indeno(1,2,3-cd)pyrene and coronene, have not been shown to significantly biodegrade even over long periods of time [7].

Because of its toxicity, creosote-treated wood does not degrade easily in the environment and requires special disposal methods. The detoxification of creosote treated wood has become more popular since this material has been classified as dangerous waste on the basis of the existing law dispositions (EU Directive 2001/90/CE).

It is generally accepted that creosote is a major wood preservative. Creosote-treated wood has commonly been used for railroad crossties and landscape facilities, as a result, creosote contamination of surface soils, segments, and groundwater is commonly observed in areas in which creosote-treated wood was used. The combustion of creosote treated wood is the main industrial treatment actually in use, however up to nowadays the great majority of bioremediation experiments concerned with creosote regards polluted soil, where different microorganisms are involved in the oxidation and subsequent mineralization of creosote components: soil bacteria or fungi, are described (Fig.3.).

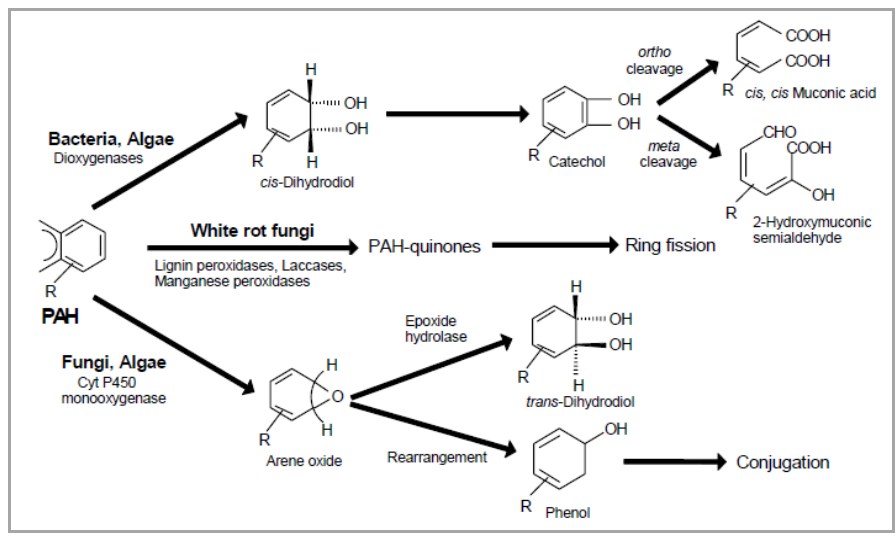

Fig. 3. Major pathways involved in the metabolism of polycyclic aromatic hydrocarbons by bacteria, fungi and algae [20].

There are a lot of articles related with bioremediation experiments concerned with creosote regards polluted soil, however, information related to wood impregnated with creosote bioremediation is not much compared to bioremediation of soil.

\section{Creosote degradation by bacteria}

Creosote is not easily degraded by microorganisms. Bacteria involved in degradation of creosote components (some PAHs, HACs, phenolic compounds) have been isolated and identified as belonging mostly to the genera Pseudomonas [21-24], Spingomonas [25], Bacillus [26] and Mycobacterium [27],[28]. Creosote biodegradation by bacteria strains limited the high- molecular-weight PAHs continued to be recalcitrant in treated soil [29]. 
Despite the removal of a majority of creosote contaminants from groundwater through biotreatment, only a slight decrease in toxicity and teratogenecity of biotreated groundwater was observed. Recent studies demonstrated that several treatments have been successful in reducing, for example, the total PAH concentration in contaminated soils, however increased the microbial mutagenicity of these soils [30]. Creosote compounds biodegradation by bacteria are used more frequently than biodegradation by fungi or removal with phytoremediation.

\section{Degradation of creosote by fungi}

The pollutants contained in the creosote-treated wood waste are also barriers to its use as landfill cover due to potential migration of contaminants into ground water. The life expectancies of creosote-treated railway ties depend on rail traffic, tie placement and environmental hazards. The service life of creosote-treated railway ties is from 30 to 50 years. Therefore, a proper disposal method should include an effective degradation of the pollutants in creosote treated wood waste. Positive results were obtained with fungi belonging to different genus are presented in Table 1 [31],[32]. High degradation was obtained with white-rot fungi Phanaerochaete crysosporium [33], Pleurotus ostreatus [34-36], Cladosporium sp. [31], Polyporus sp. [37], filamentous fungus Fusarium sp. (strain E0330) [38], ascomycetous fungus Thermoascus aurantiacus [43]. White-rot fungal species could be interesting for the treatment of wood waste because of their ability to degrade phenols and $\mathrm{PAH}$ and to grow on ligninocellulosic materials [39-41].

TABLE 1.

STUDIES ON CREOSOTE CONTAMINATED SOIL AND CREOSOTE TREATED WOOD BIOREMEDIATION BY FUNGI

\begin{tabular}{|c|c|c|}
\hline Fungi & Research findings & References \\
\hline \multicolumn{3}{|l|}{ Creosote-contaminated soil } \\
\hline $\begin{array}{l}\text { Pleurotus ostreatus, } \\
\text { Irpex lacteus }\end{array}$ & $\begin{array}{l}\text { Fungus degraded PAH with } 4-6 \text { aromatic rings more efficiently than the microbial community } \\
\text { present initially in the soil. PAH removal was higher in P. ostreatus treatments than in I. } \\
\text { lacteus. Indicates a potential for synergistic interaction between the fungus and actinobacteria in } \\
\text { bioremediation. }\end{array}$ & {$[35]$} \\
\hline $\begin{array}{l}\text { Cladosporium, Fusarium, } \\
\text { Penicillium, Aspergillus, } \\
\text { Pleurotus }\end{array}$ & $\begin{array}{l}\text { White-rot fungus belonging to the genus Pleurotus was better able to degrade creosote than } \\
\text { other organisms studied, and that mixed fungal cultures more effectively degraded creosote than } \\
\text { did pure cultures. }\end{array}$ & [31] \\
\hline Phanerochaete sordida & $\begin{array}{l}\text { Demonstrate the potential of lignin-degrading fungi in the solid-phase bioremediation of } \\
\text { creosote-contaminated soils, but, the persistence of highly toxic PAHs containing }>5 \text { rings } \\
\text { represents a significant challenge which must be overcome before the technology can be } \\
\text { considered a viable treatment option for creosote-contaminated sites. }\end{array}$ & {$[42]$} \\
\hline Pleurotus ostreatus & $\begin{array}{l}\text { P. ostreatus has an overall positive effect on the degradation of aged creosote in soil and that } \\
\text { degradation is enhanced by increased temperature and pre-treatment. }\end{array}$ & [34] \\
\hline \multicolumn{3}{|l|}{ Creosote-treated wood } \\
\hline $\begin{array}{l}\text { The fungal inoculums comprise } \\
\text { at least one creosote-tolerant } \\
\text { fungus (e.g, Antrodia radiculosa, } \\
\text { Neolentinus lepideus, etc.) }\end{array}$ & $\begin{array}{l}\text { Waste wood containing creosote is remediated or degraded by inoculating it with the fungal } \\
\text { inoculums. The inoculums and waste wood are combined until an end product is achieved that } \\
\text { is at least partially remediated or of a reduced volume. }\end{array}$ & {$[32]$} \\
\hline Pleurotus ostreatus & $\begin{array}{l}\text { Phenols are completely degraded. Some more dangerous compounds, such as methyl-PAH and } \\
5-6 \text { rings PAHs are generally well degraded. Almost complete degradation of creosote oil } \\
\text { components, also confirmed by a significant reduction of ecotoxicity. }\end{array}$ & {$[41]$} \\
\hline $\begin{array}{l}\text { A total of } 179 \text { fungal isolates was } \\
\text { recovered from } 240 \text { sampling } \\
\text { points }\end{array}$ & $\begin{array}{l}\text { There was a large difference in the fungal diversity between the surface and the inner area of } \\
\text { crosstie wastes. Heterobasidion annosum and Schizophyllum commune showed very high } \\
\text { resistance to PAHs, which indicates that these species may play a role in the degradation of } \\
\text { PAHs. }\end{array}$ & [9] \\
\hline $\begin{array}{l}\text { Agrocybe, Armillaria, } \\
\text { Auricularia, Daedalea, } \\
\text { Pleurotus, Trametes }\end{array}$ & $\begin{array}{l}\text { The most tolerant strain, Pleurotus ostreatus SMR 684, extracellular laccase and peroxidase } \\
\text { specific activities were monitored during growth in the presence of creosote-treated wood. }\end{array}$ & [40] \\
\hline Thermoascus aurantiacus & $\begin{array}{l}\text { The inoculation of cellulolytic and thermophilic fungus Thermoascus aurantiacus did not } \\
\text { accelerate the bioremediation process in degrading phenolic compounds and may have inhibited } \\
\text { the metabolic activity of composting organisms. }\end{array}$ & {$[43]$} \\
\hline
\end{tabular}

Since the low bioavailability of PAHs by bacteria, the increased bioavailability of PAHs metabolites, produced by white rot fungi, can increase their mineralization by bacteria [44]. In contrast to bacteria, fungi generally do not utilize PAHs as sole carbon and energy source, but transform them comethabolically to detoxified metabolites. The degradation process in soil proceeds as a cooperation between white rot fungi (catalyse PAHs oxidation) and bacteria (mineralise PAHs with higher water solubility and oxidise metabolites of recalcitrant). In soil treated with Pleurotus ostreatus, where the soil bacteria were almost eliminated by the fungus, mineralization of PAHs was incomplete due to accumulation of intermediary metabolites that could not be oxidised by the fungus [45], but can be mineralised by bacteria. 


\section{Phytoremediation}

Phytoremediation describes the treatment of environmental problems through the use of plants that mitigate the environmental problem without the need to excavate the contaminant material and dispose of it elsewhere. This cleaning method consists of mitigating pollutant concentrations in contaminated environment with plants able to accumulate, degrade, or eliminate various contaminants from media that contain them. There are several basic phytoremediation techniques: rizofiltration, phytoextraction, phytotransformation, phytostimulation, phytostabilization. The main advantages phytoremediation compared with other approaches are the preserve the natural structure and texture of the cleaned soil; it is low in cost and has potential to be rapid. One serious limitation is that many plant species are sensitive to contaminants [46].

The role of plants in remediation creosote and PAHs contaminations (which are the main part in creosote contaminants) presented in Table 2. PAHs can be degraded in the rhizosphere however may also interact with vegetation by accumulation in plant tissues or adsorption on root surface. Contaminant bioavailability and toxicity are critical factors in phytoremediation and bioavailability depends on lipophilicity and age, soil characteristics, such as $\mathrm{pH}$, clay and organic matter content. The PAHs are widely distributed hydrophobic organic contaminants in soil usually exhibit low bioavailability to both microorganisms and plants due to their strong affinity to the soil matrix, especially to soil organic matter which limits the application of phytoremediation [11],[45],[47].

According the literature data there are selected number of plant species which have been found to be promising candidates for phytoremediation of such persistent pollutants as PAHs and could be used as an alternative technique to reduce creosote (PAHs) levels in soils [4648] (Table 2). Plants provide root exudates with carbon, energy, nutrients, enzymes and sometimes oxygen to microbial populations in the rhizosphere. Root exudates of sugars, alcohols, and acids are annually from 10 to 20 $\%$ of plant photosynthesis [49] and provide sufficient amount of carbon and energy to support the large numbers of microbes. Root exudates are link between plants and microbes that causes the rhizosphere effect. This environmental cleaning method is effective, however evidence exists for the enhanced dissipation of PAHs in the rhizosphere when compared to nonrhizosphere soil [50-52].

TABLE 2.

STUDIES ON PHYTO-REMEDIATION WITH CREOSOTE (PAHS, PHENOLS) CONTAMINANTS IN SOIL

\begin{tabular}{|c|c|c|}
\hline $\begin{array}{l}\text { Common name of plant } \\
\text { (Scientific name of plant) }\end{array}$ & Research findings & References \\
\hline \multirow[t]{3}{*}{ Alfalfa (Medicago sativa L.). } & $\begin{array}{l}\text { The residual concentrations of pyrene in the rhizosphere soil were lower than those in the } \\
\text { non-rhizosphere soil. }\end{array}$ & {$[51]$} \\
\hline & All vegetated treatments resulted in higher phytoremediation efficiency. & [53] \\
\hline & $\begin{array}{l}\text { Arbuscular mycorrhizal inoculation and addition of the surfactant consistently promoted } \\
\text { phenanthrene dissipation in the soil }\end{array}$ & [54] \\
\hline $\begin{array}{l}\text { Alfalfa (Medicago sativa L.), tall } \\
\text { fescue (Festuca arundinacea } \\
\text { Schreb.). }\end{array}$ & $\begin{array}{l}\text { Cropping promoted the dissipation of soil PAHs. Tall fescue gave greater removal of soil } \\
\text { PAHs than alfalfa, intercropping was more effective than monoculture. Stimulates PAH } \\
\text { degrading bacterial population. }\end{array}$ & {$[44]$} \\
\hline $\begin{array}{l}\text { Alfalfa (Medicago sativa), ryegrass } \\
\text { (Lolium perenne). }\end{array}$ & $\begin{array}{l}\text { Are potential plants for phytoremediation. The interactions among the consortia of plant } \\
\text { root exudates, microorganisms, and amended compost in rhizosphere soils could facilitate } \\
\text { bioavailability of pyrene and subsequently enhance its dissipation }\end{array}$ & {$[52]$} \\
\hline Ryegrass (Lolium perenne L.). & $\begin{array}{l}\text { Enhances dissipation or biotransformation of a large range of PAHs including } 5 \text { and 6-ring } \\
\text { PAHs. The major part of PAHs dissipation in rhizosphere soil was due to biodegradation } \\
\text { or biotransformation. }\end{array}$ & {$[50],[55]$} \\
\hline Willows (Salix Viminalis). & $\begin{array}{l}\text { Enhanced the degradation of all PAHs, most likely by the pronounced rhizosphere effect } \\
\text { on the activity of active microorganisms, including PAH degraders. }\end{array}$ & {$[56]$} \\
\hline $\begin{array}{l}\text { Tall fescue (Festuca arundinacea), } \\
\text { kentucky bluegrass (Poa pratensis), } \\
\text { wild rye (Elymus canadensis). }\end{array}$ & $\begin{array}{l}\text { Tall fescue is more suitable for use in phytoremediation. Plant growth promoting } \\
\text { rhizobacteria were evaluated for plant growth promotion and protection of plants from } \\
\text { contaminant toxicity. }\end{array}$ & [46] \\
\hline $\begin{array}{l}\text { Tall fescue (Festuca arundinacea), } \\
\text { red fescue (Festuca rubra), } \\
\text { ryegrass (Lolium perenne), red } \\
\text { clover (Trifolium pratense), white } \\
\text { clover (Trifolium repens). }\end{array}$ & $\begin{array}{l}\text { In soils spiked with pure PAHs or coal tar the rate of loss of PAHs is much greater than in } \\
\text { historically contaminated soils. There were clear differences in the losses of the PAHs } \\
\text { depending on ring size amongst the } 16 \text { PAHs tested. }\end{array}$ & [57] \\
\hline $\begin{array}{l}\text { Bean (Vicia faba), corn (Zea mays), } \\
\text { wheat (Triticum aestivum). }\end{array}$ & All vegetated treatments resulted in higher phytoremediation efficiency. & {$[58]$} \\
\hline Vetch (Vicia sativa L.). & $\begin{array}{l}\text { Vetch could tolerate and remove high phenol concentrations, avoiding serious phytotoxic } \\
\text { effects. Thus, vetch could be considered an interesting tool in the field of } \\
\text { phytoremediation. }\end{array}$ & [59] \\
\hline
\end{tabular}


Addition of surfactants has been explored in the cleanup of contaminated soils [60]; there are few reports of their application in phytoremediation, they found that the presence of the surfactant enhanced PAH degradation by a rhizosphere effect on the microbial activity and by increased bioavailability [54],[56].

\section{CONCLUSION}

Creosote, which is a common preservative used in wood treating processes, consists of different polycyclic aromatic, phenolic hydrocarbons and heterocyclic compounds. Because of their toxicity and their mutagenic and carcinogenic properties polycyclic aromatic hydrocarbons are classified as ubiquitous contaminants of highest concern in the environment. Toxic, environmental-persistent chemicals are resistant to degradation in the natural environment. Creosote contaminants do not degrade easily in the environment and require special disposal methods as there are not so many creosote-tolerant microorganisms, fungi and plant species.

Although many studies have been conducted to develop useful methods of bioremediation using microbes, fungi or plants, there is a limited number of species that can be used. Therefore, predictions of creosote dissipation from laboratory amended soil or treated creosote wood do not reflect the true situation in the field conditions. The further studies must be conducted to identify various species and fungal communities, microbial and plant species capable of bioremediation not only in lab conditions, but must show good results in field testing. Forthcoming studies should be the basis for the development of efficient technology, suitable for both insitu and ex-situ processing of creosote-contaminated soil or large amounts of creosote-treated wood.

\section{$\mathrm{V}$ ACKNOWLEDGMENTS}

Partial financial support from the project BIOREM (VP1-3.1-ŠMM-10-V-023-010) is acknowledged.

\section{REFERENCES}

[1] Becker L., Matuschek G., Lenoir D., Kettrup A. Leaching behavior of wood treated with creosote. Chemosphere, 42. 2001, pp. 301308 .

[2] Moret S., Purcano G., Conte L.S., Polycyclic aromatic hydrocarbon (PAH) content of soil and olives collected in areas contaminated with creosote released from old railway ties. Science of the Total Environment, 386. 2007, pp. 1-8.

[3] Mueller J.G., Chapman P.J., Pritchard P.H. Creosote-contaminated sites. Environ. Sci. Technol., 23(10). 1989, pp. 1197-1201.

[4] Hartnik T., Norli H. R., Eggen T., Breedvelt G.D. Bioassaydirected identification of toxic organic compounds in creosotecontaminated groundwater. Chemosphere, 66. 2007, pp. 435-443.

[5] Mueller J. G., Middaugh D. P., Lantz S. E., Chapman P. J. Biodegradation of creosote and pentachlorophenol in contaminated groundwater: chemical and biological assessment. Applied and Environmental Microbiology, 57(5). 1991, pp. 1277-1285.

[6] Breedveld G. D., Karlsen D.A., Estimating the avaibility of polycyclic aromatic hydrocarbons for bioremediation of creosote contaminated soil. Appl Microbiol Biotechnol, 54. 2000, pp. 255 261.

[7] Grant R.J., Muckian L.M., Clipson N.J.W., Doyle E.M. Microbial community changes during the bioremediation of creosotecontaminated soil. Letters in applied Microbiology, 44. 2007, pp. 293-300.
[8] Skupinska K., Misiewicz I., Kasprycka-Guttman T.. Polycyclic Aromatic Hydrocarbons: Physiciohemical Properties, Environmental Appearance And Impacton Living Organisms. Acta Poloniae Pharmaceutica - Drug Research, 61(3). 2004, pp. 233240 .

[9] Kim M.-J., Lee H., Choi Y.-S., Kim G.-H., Huh N.-Y., Lee S., Lim, Y.W., Lee S.-S., Kim J.-J. Diversity of fungi in creosote-treated crosstie wastes and their resistance to polycyclic aromatic hydrocarbons. Antonie van Leeuwenhoek, 97. 2010, pp. 377-387.

[10] Carriere P.P.E, Mesania F.A. Enhanced biodegradation of creosote-contaminated soil. Waste Management, 15(8). 1995, pp. $579-583$.

[11] Kulik N., Goi A., Trapido M., Tuhkanen T. Degradation of polycyclic aromatic hydrocarbons by combined chemical preoxidation and bioremediation in creosote contaminated soil. Journal of Environmental Management, 78. 2006, pp. 382-391.

[12] Guerin T. F. Bioremediation of phenols and polycyclic aromatic hydrocarbons in creosote contaminated soil using ex-situ landtreatment. Journal of Hazardous materials, B65. 1999, pp. 305315.

[13] Michalowicz J., Duda W. Phenols-Sources and Toxicity. Polish J. of Environ. Stu., 3. 2007, pp. 347-362.

[14] Cerniglia C. E. Biodegradation of polycyclic aromatic hydrocarbons. Current Opinion in Biotechnology, 4. 1993, pp.331338.

[15] White A. P., Claxton L.D. Mutagens in contaminated soil: a review. Mutation Research, 567. 2004, pp. 227-345.

[16] Padma T. V., Hale R. C., Roberts M. H., Lipcius R. N. Toxicity of Creosote Water-Soluble Fractions Generated from Contaminated Sediments to the Bay Mysid. Ecotoxicology and Environmental Safety, 42, 1999, pp. 171-176.

[17] U.S. Department of Health and Human Services. Toxilogical profile for wood creosote, coal tar creosote, coal tar, coal tar pitch and coal tar pitch volatiles. 2002.

[18] Coal Tar Creosote. Consise International Chemical Assesment Document 62. World Health Organization Geneva. 2004.

[19] Agency for Toxic Substances and Disease Registry (ATSDR). 2002. Toxicological profile for creosote. Atlanta, GA: U.S. Department of Health and Human Services, Public Health Service.

[20] Mueller J.G., Cerniglia C.E., Pritchard P.H. Bioremediation of environments contaminated by polycyclic aromatic hydrocarbons. In: Crawford RL, Crawford DL (eds) Bioremediation: Principles and Applications, Cambridge University Press, U.K., 1996, pp 1215-1294.

[21] Zhang Z., Zhaowei H., Yang C.; Cuiqing M., Tao F., Xu P. Degradation of n-alkanes and polycyclic aromatic hydrocarbons in petroleum by a newly isolated Pseudomonas aeruginosa DQ8. Bioresourse Technology, 102. 2011, pp. 4111-4116.

[22] Gajewska J., Miszczyk A., Markiewicz Z. Tolerance to creosote oil of bacteria of the genus Pseudomonas isolated from the wood of coniferous trees. Acta microbiologica Polonica Vol. 52, No 4, 2003; 387-394.

[23] Stefan J. Grimberg, William T. Stringfellow, And Michael D. Aitken Quantifying the Biodegradation of Phenanthrene by Pseudomonas stutzeri P16 in the Presence of a Nonionic Surfactant. Applied And Environmental Microbiology Vol. 62, No. 7,1996, pp. 2387-2392

[24] Doong R., Wen-gang Lei Solubilization and mineralization of polycyclic aromatic hydrocarbons by Pseudomonas putida in the presence of surfactant. Journal of Hazardous Materials B96. 2003, pp. 15-27.

[25] Rentz J. A., Alvarez P. J. J., Schnoor J. L. Benzo[a]pyrene degradation by Sphingomonas yanoikuyae JAR02. Environmental Pollution, 151. 2007, pp. 669-677.

[26] Zhao Z., Wong J. W-C. Rapid biodegradation of benzo[a]pyrene by Bacillus subtilis BUM under thermophilic condition. Environmental Engineering Science, 27(11). 2010, pp. 939-945.

[27] Heitkamp M. A., Freeman J. P., Miller D. W., Cerniglia C. E. Pyrene degradation by a Mycobacterium sp.: identification of ring oxidation and ring fission products. Applied and Environmental Microbiology, 54(10). 1988, pp. 2556-2565.

[28] Johnsena A. R., Wickb L. Y., Harmsb H. Principles of microbial PAH-degradation in soil. Environmental Pollution, 133. 2005, pp. 71-84.

[29] Breedveld G., Karlsen D. Estimating. The availability of polycyclic aromatic hydrocarbons for bioremediation of creosote 
contaminated soils. Applied Microbiology and Biotechnology, 54(20). 2000, pp. 255-261.

[30] Brooks L., Hughes T., Claxton L., Austern B., Brenner R., Kremer F. Bioassay-directed fractionation and chemical identification of mutagens in bioremediarted soils. Environmental Health perspective, 106(6). 1998, pp. 1435-1440.

[31] Atagana H. I. Bioremediation of creosote-contaminated soil: a pilot-scale land farming evaluation. World J Microbiol Biotechnol, 19. 2003, pp. 571-581.

[32] Illman B. L., Yang V.W., Ferge L.A., "Fungal degradation and bioremediation system for creosote-treated wood", U. S. Patent 6,387,689 B1, May 14, 2002.

[33] Barclay C.D., Farquhar G.F., Legge R.L. Biodegradation and sorption of polyaromatic hydrocarbons by Phanerochaete chrysosporium. Appl Microbiol Biotechnol. 42(6). 1995, pp.958963.

[34] Eggen T., Sveum P.. Decontamination of aged creosote polluted soil: the influence of temperature, white rot fungus Pleurotus ostreatus, and pre-treatment. International Biodeterioraton \& Biodegradation, 43. 1999, pp. 125-133.

[35] Byss M., Elhottová D., Tlíska J., Baldrian P. Fungal bioremediation of the creosote-contaminated soil: Influence of Pleurotus ostreatus and Irpex lacteus on polycyclic aromatic hydrocarbons removal and soil microbial community composition in the laboratory-scale study. Chemosphere, 73. 2008, pp. 15181523 .

[36] Pozdnyakova N. N., Nikitina V. E., Turovskaya O. V. Bioremediation of Oil-polluted Soil with an Association Including the Fungus Pleurotus ostreatus and Soil Microflora. Applied Biochemistry and Microbiology, 44(1). 2008, pp. 60-65.

[37] Hadibarata T. Oxidative Degradation of Benzo[a]pyrene by the Ligninolytic Fungi. Interdisciplinary Studies on Environmental Chemistry - Environmental Research in Asia, Eds., Obayashi Y., Isobe T., Subramanian A., Suzuki S., Tanabe S., pp. 309-316, 2009.

[38] Chulalaksananukul S.,. Gadd G. M, Sangvanich P., Sihanonth P., Piapukiew J., Vangnai A. S. Biodegradation of benzo(a)pyrene by a newly isolated Fusarium sp. FEMS Microbiol Lett, 262. 2006, pp. 99-106.

[39] Kurt S., Buyukalaca S. Yield performances and changes in enzyme activities of Pleurotus spp. ( $P$. ostreatus and P. sajor-caju) cultivated on different agricultural wastes. Bioresource Technology, 101. 2010, pp. 3164-3169.

[40] Galli E., Brancaleoni E., Di Mario F., Donati E., Frattoni M., Polcaro C.M., Rapanà P. Mycelium growth and degradation of creosote-treated wood by basydiomycetes. Chemosphere, 72 . 2008, pp. 1069-1072.

[41] Polcaro CM, Brancaleoni E, Donati E, Frattoni M, Galli E, Migliore L, Rapanà P. Fungal bioremediation of creosote-treated wood: a laboratory scale study on creosote components degradation by Pleurotus ostreatus mycelium. Bulletin of Environmental Contamination and Toxicology, Vol. 81, Issue 2, 2008, pp 180-184.

[42] Davis M. W., Glaser J. A., Evans J. W, Lamar R. T. Field Evaluation of the Lignin-Degrading Fungus Phanerochaete sordida to Treat Creosote-Contaminated Soil. Environ. Sci. Technol., 27(12). 1993, pp.2572-2576.

[43] Ghaly A. E., Zhang B., Dave D. Biodegradation of Phenolic Compounds in Creosote Treated Wood Waste by a Composting Microbial Culture Augmented with the Fungus Thermoascus aurantiacus. American Journal of Biochemistry and Biotechnology, 7(2). 2011, pp. 90-103.

[44] San M., Dengqiang Fu, Ying Teng, Yuanyuan Shen, Yongming Luo, Zhengao Li, Peter Christie. In situ phytoremediation of PAHcontaminated soil by intercropping alfalfa (Medicago sativa L.) with tall fescue (Festuca arundinacea Schreb.) and associated soil microbial activity. J Soils Sediments, 11. 2011, pp. 980-989.

[45] Andersson B.E., Lundstedt S., Tornberg K., Schnurer Y., Oberg L.G., Mattiasson B..Incomplete degradation of polycyclic aromatic hydrocarbons in soil inoculated with wood-rotting fungi and their effect on the indigenous soil bacteria. Environmental Toxicology and Chemistry, 22. (2003), pp. 1238-1243.

[46] Huang X. D, El-Alawi Y., Penrose D. M., Glick B. R., Greenberg B. M. A multi-process phytoremediation system for removal of polycyclic aromatic hydrocarbons from contaminated soils. Environ Pollut, 130. 2004, pp.465-476.

[47] Chen Y.C., Katherinebanks M, Paulschwab A. Pyrene degradation in the rhizosphere of tall fescue (Festuca arundinacea) and switchgrass (Panicum virgatum L). Environ Sci Technol, 37. 2003, pp. $5778-5782$.

[48] Phillips L.A., Greer C.W., Farrell R.E., Germida J.J. Field-scale assessment of weathered hydrocarbon degradation by mixed and single plant treatment. Appl Soil Ecol, 42. 2009, pp. 7-17.

[49] Schnorr J.L., Licht L.A., McCutcheon S.C., Wolfe N.L., Carriera L.H., Phytoremediation of Organic and Nutrient Contaminants, Environ. Sci. Technol., 29. 1995, pp. 318-323.

[50] Binet Ph., Portal J.M., Leyval C. Fate of polycyclic aromatic hydrocarbons $(\mathrm{PAH})$ in the rhizosphere and mycorrhizosphere of ryegrass. Plant and Soil, 227. 2000, pp. 207-213.

[51] Fan S., Li P., Gong Z., Ren W., He N. Promotion of pyrene degradation in rhizosphere of alfalfa (Medicago sativa L.). Chemosphere, 71(8). 2008, pp. 1593-1598.

[52] Wang M.C., Chen Y.T., Chen S.H., ChangChien S.W., SunkaraS.V. Phytoremediation of pyrene contaminated soils amended with compost and planted with ryegrass and alfalfa. Chemosphere, 87. 2012, pp. 217-225

[53] Hamdi, B., Benzarti S., Aoyama, J., Jedidi N., Rehabilitation of degraded soils containing aged PAHs based on phytoremediation with alfalfa (Medicago sativa L.). International Biodeterior and Biodegradation, 67. 2012, pp. 40-47.

[54] Wu N., Zhang Sh., Huang H., Christie P. Enhanced dissipation of phenanthrene in spiked soil by arbuscular mycorrhizal alfalfa combined with a non-ionic surfactant amendment. Science Of The Total Environment, 394. 2008, pp. 230-236.

[55] Binet Ph., Portal J.M., Leyval C. Dissipation of 3-6-ring polycyclic aromatic hydrocarbons in the rhizosphere of ryegrass. Soil Biology \& Biochemistry, 32. 2000, pp. 2011-2017.

[56] Hultgren J., Pizzul L., Castillo M.P., U.Granhall. Degradation of $\mathrm{PAH}$ in a Creosote-Contaminated Soil. A Comparison Between the Effects of Willows (Salix Viminalis), Wheat Straw and A Nonionic Surfactant. International Journal of Phytoremediation, 12. 2010, pp. 54-66.

[57] Smith M.J., Flowers T.H., Duncan H.J., Saito H. Study of PAH dissipation and phytoremediation in soils: Comparing freshly spiked with weathered soil from a former coking works. Journal of Hazardous Materials, 192. 2011, pp. 1219-1225.

[58] Diab E. A. Phytoremediation of Polycyclic Aromatic Hydrocarbons (Pahs) in a Polluted Desert Soil, with Special Reference to the Biodegradation of the Carcinogenic Pahs. Australian Journal of Basic and Applied Sciences, 2(3). 2008, pp. 757-762.

[59] Ibáñez S.G., Sosa Alderete L.G., Medina M.I., Agostini E. Phytoremediation of phenol using Vicia sativa L. plants and its antioxidative response. Environ Sci Pollut Res Int., 19(5). 2012, pp. 1555-1562.

[60] Zhu L., Feng Sh. Synergistic solubilization of polycyclic aromatic hydrocarbons by mixed anionic-nonionic surfactants. Chemosphere, 53. 2003, pp. 459-467. 